\title{
Potret Kegelisahan Sekolah dalam Melaksanakan Ujian Nasional
}

\author{
M. Imam Zamroni \\ Universitas Gajah Mada \\ imam_z@yahoo.com
}

The policy of National Examination (NE) standardisation has caused schools to be trapped in a practical effort to help student to be passed, focussing on merely repetitive test practices of examination subjects. Learning has been considered not as a process of developing or maturing, but a process to gain high grades and to pass the NE. As a consequence, teaching-learning process has resulted in fear of failing the NE for studets. Teachers have also been stressed and depressed, because on one hand they have cultivated social empathy, but on the other hand, they have been forced to engage in practices even they have not believed in, and in search for 'bypasses' for the sake of students' successful in NE. Therefore, the policy of standardisation of passing grades in the NE should be changed to reflect the spirit of decentralization and regional autonomy, and the appreciation of diversity of school qualities and capacities for teaching-learning.

\section{Keywords: Policy, National Examination, pass, fear.}

\section{Pendahuluan}

K ebijakan pemerintah tentang Ujian Nasional (UN) telah membuat lembaga pendidikan kita kalang-kabut dan terperosok dalam lubang hitam disorientasi pendidikan. Karena sekolah harus mempersiapkan siswanya dengan cepat, instant dan sangat pragmatis, seperti menambah jam belajar untuk membahas materi UN, menyelenggarakan try out, karena pada tahun 2008 jumlah mata pelajaran yang diujikan menjadi dua kali lipat, dari tiga menjadi enam mata pelajaran. Singkatnya siswa di drillagar bisa lulus dalam ritual tahunan yang bernama UN tanpa mempertimbangkan kapasitas dan kemampuan seorang siswa (Zamroni, 2008c). Ini artinya, praktik pendidikan telah terjebak pada logika pelatihan yang mekanistik dan pragmatis, sehingga akan menyebabkan involusi pendidikan (Harefa, 2000: 60). Di samping itu juga terjadi dehumanisasi di sekolah yang mengabaikan eksistensi siswa sebagai manusia pembelajar yang memiliki keragaman potensi. Padahal sampai saat ini standarisasi kelulusan masih terus menjadi bahan perdebatan (debatable), apakah dapat meningkatkan kualitas pendidikan secara subtansial ataupun tidak, sehingga diperlukan kajian yang mendalam. UN merupakan instrumen untuk melaksanakan evaluasi terhadap proses pembelajaran yang telah dilakukan oleh guru dan siswa.

\section{Kajian Pustaka}

MenurutAnas Sudiono (2001: 29) ruang lingkup evaluasi meliputi tiga aspek yaitu (1) evaluasi mengenai program pengajaran (2) evaluasi mengenai proses pengajaran (3) evaluasi mengenai hasil belajar (hasil pengajaran). Melihat ruang lingkup evaluasi tersebut maka yang ditekankan adalah prosesnya yang alamiah sehingga tidak perlu melakukan drill sebagaimana banyak dilakukan oleh sekolah-sekolah pada umumnya untuk menghadapi UN. Hasil dari drill tentunya bukanlah cerminan dari proses 
Potret Kegelisahan Sekolah dalam...; M. Imam Zamroni, M.Si

pembelajaran yang dilakukan secara terus menerus dan berkesinambungan yang melibatkan guru dan siswa. Dari sini kita tahu bahwa UN tidak bisa dijadikan tolak ukur evaluasi proses pembalajaran yang alamiah, karena telah terdistorsi dengan kegiatankegiatan pragmatis dan mekanis seperti pembahasan soal-soal yang terhadahulu guna memprediksi soal yang akan datang. Jika cara ini tidak bisa menjadi solusi, maka dicarilah "jalan pintas" yang lain.

Praktik kecurangan, menipulasi dan ketidakjujuran ditemukan dalam pelaksanaan UN, baik oleh guru maupun siswa, ditemukan dengan modus yang amat beragam. Seperti dalam kasus yang dilakukan oleh 18 guru untuk "menyelamatkan" siswanya dengan mengganti jawaban soal bahasa Inggris di Sekolah Menengah Atas Negeri 2 Lubuk Pakam, kabupaten Deli Serdang, Sumatra Utara. Di tempat yang berbeda, 5 guru di sebuah Madrasah Tsanawiyah, di kabupaten Pandeglang, Propinsi Banten melakukan praktik kecurangan dengan menandai 52 soal Bahasa Indonesia agar siswa terbantu dalam mengerjakannya. Akhirnya, guru tersebut ditetapkan sebagai tersangka kebocoran soal UN (Kompas, 03/05/2008). Tak berlebihan jika dikatakan bahwa, guru lebih gelisah dibandingkan dengan siswa dalam menghadapi ritual tahunan yang disebut dengan UN disetiap sekolah, baik sekolah favorit yang memiliki fasilitas pembelajaran yang memadai, terlebih sekolah "tertinggal" dengan fasilitas minim dan serba terbatas.

Dalam kasus ini, tentunya kita tidak bisa serta-merta menyalahkan guru yang mempunyai empati sosial (social emphatic) dan rasa khawatir terhadap anak didiknya, akan tetapi tindakan tersebut dipicu oleh kebijakan pemerintah yang "antirealitas", tidak melihat kondisi riil pendidikan di Indonesia, sehingga menimbulkan kegelisahan dan keserasahan. Tidak sedikit kondisi sekolah yang masih dalam keadaan terpuruk, fasilitas minim dan gedung rusak parah, namun di dalamnya masih berlangsung proses belajar mengajar yang melibatkan guru dan murid dalam satu atap yang sudah sangat rentan ambruk sehingga membahayakan keberadaan guru dan murid tersebut. Fasilitas yang minim tentunya mempunyai pengaruh yang besar terhadap kualitas pembelajaran yang diselenggarakan dan outputyang dihasilkan.

Di pusat-pusat perkotaan seperti Jakarta, Semarang, Surabaya dan Medan saja masih banyak gedung sekolah yang tidak layak pakai, apalagi di daerah pinggiran dan daerah pelosok tentu lebih banyak lagi. Data dari Depdiknas sebagai hasil Rembuknas Pendidikan 2007 menunjukkan pada tahun 2003 terdapat 531.186 ruang kelas yang rusak, dan sejumlah 360.219 telah diperbaiki, sisanya akan diperbiaki pada tahun 2008. Dari sejumlah ruangan sekolah yang rusak tersebut, 52 persen atau sekitar 276.695 unit terdapat di pulau Jawa. Hal ini masih ditambah dengan tingginya angka putus sekolah (drop out) di pada tingkat sekolah dasar. Tercatat tahun 2002/03-2003/04 sebanyak 767.835 siswa, tahun 2003/04-2004/05 sebanyak 777.010 siswa, tahun 2004/05-2005/06 sebanyak 824.684 siswa dan tahun 2005/062006/07 sebanyak 615.411 siswa (Depdiknas, 2008, dalam Kompas, 12/08/2008) yang menjadi faktor utama penyebab tingginya angka putus sekolah adalah masalah keterpurukan ekonomi masyarakat.

Akibat keterpurukan ekonomi tersebut juga menyebabkan buruknya kondisi sekolah, terutama gedung sekolah sebagai sarana pembelajaran, ruang perpustakaan maupun fasilitas yang lainnya. Minimnya fasilitas pembelajaran mempunyai dampak yang amat serius bagi prestasi siswa dan peningkatan kualitas pendidikan secara keseluruhan. Adanya kebijakan standarisasi kelulusan UN yang masih dirasakan cukup 
UNISIA, Vol. XXXI No. 69 September 2008

tinggi bagi sekolah-sekolah terbelakang mengakibatkan mereka merasa tertekan. Adalah suatu kewajaran bila adanya "tekanan" dari pemerintah untuk memenuhi standar kelulusan tersebut mengakibatkan munculnya inisiatif untuk mencari "jalan pintas" dengan cepat dan instant. Pendeknya UN juga menjadi pemicu berkembangnya mental pragmatisme di sekolah, baik dikalangan siswa maupun guru. Sialnya lagi, dalam kasus standarisasi kelulusan dalam UN, siswa selalu menjadi "kelinci percobaan" atas kebijakan pemerintah.

Dalam proses penyelenggaraan pembelajaran yang bertumpu pada pengejaran angka dan standar kelulusan, siswa tidak ditempatkan sebagai subyek pembelajaran dan pribadi-pribadi yang unik, akan tetapi sebagai obyek yang harus menguasai berbagai macam materi UN tanpa mempertimbangkan kapasitas siswa secara manusiawi. Inilah yang disebut dengan konsep pendidikan gaya bank (banking concept of education) yang dapat membius dan mematikan daya kreatif siswa (Freire, 2000: 55). Akhirnya siswa mengalami gelisah, stress, frustasi, bahkan depresi karena dihinggapi rasa takut dan malu jika gagal dalam UN. Berdasarkan pertemuan dari beberapa guru yang saya lakukan, tidak sedikit siswa yang sedih dan menangis setelah keluar dari ruangan dalam pelaksanaan UN karena tidak dapat mengerjakan soal yang diujikan pada mata pelajaran tertentu, padahal menurut akunya, dalam satu tahun terakhir ini ribuan soal telah dipelajarinya, namun hanya seidkit sekali yang keluar dalam soal ujian. Menurut Pierre Bourdieu (1990:1), inilah adalah praktik kekerasan simbolik (symbolic violence) yang amat berbahaya bagi perkembangan psikologis siswa. Paulo Freire (2000:19) menganggap hal itu sebagai praktik dehumanisasi (dehumanization) di dunia pendidikan yang bertentangan dengan fitrah manusia, disisi lain juga mempunyai dampak psikologis yang dapat mengganggu perkembangan mental anak (mental disorder) dalam mengarungi kehidupan tahap selanjutnya (Windhu, 2000: 14).

Tulisan ini hendak mendiskusikan dampak yang ditimbulkan adanya kebijakan standarisasi kelulusan yang masih dianggap oleh sekolah terlalu tinggi oleh berbagai macam sekolah. Apakah kebijakan standarisasi kelulusan yang sudah diterapkan oleh pemerintah dalam beberapa tahun terakhir dapat meningkatkan kualitas pendidikan? Dan bagaimana kegelisahan guru, siswa dan orang tua siswa dalam menghadapi ritual tahunan yang bernama UN? Terkait dengan kebijakan pemberlakukan standarisasi kelulusan dalam UN, kajian-kajian yang ada hanya bersifat normatif, hanya melakukan analisis kebijakan dan tidak melihat realitas praksis pendidikan, seperti yang dilakukan oleh Zakaria (2005), dan Darmaningtyas (2007). Benediktus Widi Nugroho (2008), mencoba untuk menguraikan dampak buruk UN, namun hanya pada lingkup sekolah saja. Tulisan tersebut tidak menjelaskan secara panjang lebar tentang kondisi orang tua siswa yang juga merasakan dampaknya. Tulisan ini berusaha untuk melihat dua sisi, kebijakan dan pelaksanaannya. Melihat konteks nasional dengan melaihat realitas praksis pendidikan yang menitikberatkan pada aspek emplikasi kebijakan yang diberlakukan yang didasarkan temuantemuan dalam pada serangkaian wawancara yang dilakukan dengan guru, siswa dan orang tua siswa. Sehingga tulisan ini lebih bersifat evaluatif dan refleksi kritis.

Dalam satu dekade terakhir kebijakan pemerintah di dunia pendidikan terus berubah, meski kebijakan tersebut tidak merubah aspek subtansial persoalan di dunia 
Potret Kegelisahan Sekolah dalam...; M. Imam Zamroni, M.Si

pendidikan, seperti perubahan nama UN yang terus-menerus, padahal subtansinya sama. Adapun implikasi kebijakan tentang UN tersebut sebagaimana digambarkan oleh Darmanintyas (2007), pertama, Ujian Negara (1945-1971), pada periode tersebut ujian sepenuhnya dilakukan oleh pemerintah, baik penyiapan bahan, pelaksanaan, maupun penetapan kelulusan siswa. Hasilnya tingkat kelulusan sangat rendah tapi mutunya sangat tinggi, sehingga dapat dipakai sebagai bahan seleksi masuk ke jenjang pendidikan yang lebih tinggi. Akan tetapi kebijakan ini juga tak luput dari kritik, karena banyaknya peserta ujian yang tidak lulus.

Kedua, ujian sekolah (1971-1983), ujian ini sepenuhnya dilakukan oleh sekolah, baik penyiapan bahan, pelaksanaan, maupun penetapan kelulusan siswa. Sekolah yang sudah mempunyai status minimal diakui memiliki otoritas untuk menyelenggarakan ujian sendiri dan sekaligus menentukan kelulusan, sehingga tingkat kelulusan cukup tinggi, rata-rata 100 persen dalam setiap sekolah. Oleh karena tidak ada standar mutu, konsekuensinya hasil ujian tidak dapat digunakan sebagai mekanisme penerimaan siswa ke jenjang yang lebih tinggi. Al hasil, seleksi penerimaan siswa baru ke jenjang pendidikan yang lebih tinggi dilakukan dengan sistem tes oleh masing-masing sekolah dan ini membuka kesempatan kolusi dan nepotisme dengan motif menggunakan uang sogok atau uang suap yang mulai mendistorsi moralitas pendidikan.

Ketiga, EBTANAS (Evaluasi Belajar Nasional, 1983-2002). Ebtanas ini merupakan kebijakan setengah-setengah: setengah Ujian Negara dan setengah Ujian Sekolah. 5-7 mata pelajaran menjadi kewenangan pusat (EBTANAS) dan 7-9 mata pelajaran kewenangan sekolah (EBTA). Penyelenggaraan dan kelulusan ditetapkan sekolah sehingga tidak ada batas lulus. Tingkat kelulusan rata-rata hampir 100 persen (Zakaria, 2005). Kelemahan sistem ini adalah sering terjadi mark up nilai yang dilakukan secara struktural dan sistemik terutama bila Daftar Ebtanas Murni (DANEM) siswa jelek atau sangat jelek. Kebijakan ini mendapatkan kritik tajam, karena dinilai telah mereduksi makna pendidikan hanya untuk mencapai DANEM saja. Sehingga terjadi diskriminasi yang luar biasanya terhadap mata pelajaran di sekolah antara yang di EBTANAS-kan dan tidak di EBTANAS-kan. Kemudian tahun 2002/2003 pemerintah mengganti EBTANAS dengan UAN (Ujian Akhir Nasional) dan setelah satu tahun 2003/2004 kemudian diganti lagi menjadi UN (Ujian Nasional) meskipun subtansinya sama. Ibarat kacang hanya berubah kulitnya saja, namun rasa, aroma dan kualitasnya tetap sama tanpa ada inovasi dan kebaruan yang berarti.

Di dalam kebijakan UN, pemerintah selalu menaikkan standar kelulusan, mulai dari tahun 2002/2003 standar nilainya 3,01 dan pada tahun $2007 / 2008$ standar nilainya 5,01. Ironisnya, peningkatan standar kelulusan dalam UN yang sudah diterapkan dalam lima tahun terakhir tidak diiringi dengan penyediaan kelengkapan fasilitas pembelajaran di sekolah, terutama sekolah yang berada di daerah terpencil. Singkatnya, sekolah hanya "dipaksa" untuk memenuhi standar kelulusan yang sudah ditetapkan oleh pemerintah pusat tanpa dibarengi dengan pertimbangan-pertimbangan yang matang dan penelitian-penelitian terhadap kondisi riil sekolah-sekolah yang ada di Indonesia. Sehingga siswa kemudian menjadi komoditas bagi lembaga-lembaga bimbingan belajar yang seolah-olah menjanjikan keberhasilan dalam menempuh UN yang semu dan absurd.

Sejauh pengetahuan saya, sampai tahun 2008 ini belum ada penelitian yang 
UNISIA, Vol. XXXI No. 69 September 2008

membuktikan bahwa peningkatan standar kelulusan dapat sekaligus meningkatkan kualitas pendidikan secara keseluruhan. Padahal dampak dari kebijakan tersebut telah mengakibatkan semakin banyaknya praktik tindakan kriminal dan kecurangankecurangan di lingkungan pendidikan saat UN sedang berlangsung dan tentunya telah merusak moralitas pendidikan di Indonesia. Guru, siswa dan pihak-pihak terkait akhirnya "berkompromi" untuk melakukan tindakantindakan yang tidak dibenarkan secara hukum untuk mendapatkan predikat lulus dengan nilai yang tinggi. "Jalan pintas" dan praktik-praktik inkonstitusional tersebut seolah-olah dianggap "sah dan pantas", meskipun telah mencoreng dunia pendidikan dan bangsa Indonesia secara keseluruhan . Jika kebijakan standarisasi kelulusan ini masih terus diterapkan, tanpa mempertimbangkan kondisi sekolah yang amat beragam, maka niscaya sekolah sebagai institusi pendidikan akan semakin kreatif dalam melakukan praktik-praktik manipulatif dan kompromistik yang akan mengakibatkan terjadinya demorasisasi bangsa.

Di samping itu, meskipun UN dapat memacu motivasi siswa untuk belajar, akan tetapi beban sosial dan psikologis yang ditanggung oleh siswa dan guru terlalu tinggi. Siswa akan malu jika tidak dapat lulus dengan standar kelulusan yang sudah ditetapkan, begitu pula dengan guru akan merasa sangat malu jika ada siswanya yang tidak lulus dan tentunya secara institusional lembaga sekolah juga akan tercoreng. Imbas bagi sekolah, hal ini juga akan menimbulkan semakin sulitnya mendapatkan siswa pada tahun ajaran baru karena sekolah yang bersangkutan akan dianggap sebagai sekolah yang tidak berkualitas atau merusak reputasi sekolah, dan jika keadaan ini dibiarkan, maka akan semakin banyak sekolah yang akan "mati", terutama sekolah-sekolah swasta karena tidak mendapatkan siswa. Padahal "nafas kehidupan" sekolah swasta adalah dari banyaknya siswa yang diperolehnya saat tahun ajaran baru. Hal ini sebagaimana diberitakan di berbagai media cetak, baik media cetak berskala nasional maupun media cetak berskala lokal.

Berangkat dari persoalan itulah maka, model evaluasi yang diterapkan dalam UN harus dirubah, dengan mempertimbangkan kondisi riil sekolah dengan memberikan perlakuan (treatment) yang berbeda bagi sekolah yang "kurang mampu" yang didasarkan pada prinsip desentralisasi pendidikan yaitu: memberikan kewenangan yang lebih luas kepada pemerintah daerah dalam kebijakan pada sektor pendidikan khususnya (Jalal dan Supriyadi, 2001: 122). Sentralisasi evaluasi yang dilakukan oleh pemerintah telah mengabaikan keragaman kualitas pendidikan pada level praksis-sekolah. Di samping itu, disparitas kualitas sekolah yang berada di pusat perkotaan dan perdesaan sudah menjadi rahasia umum. Oleh karenanya, perumusan kebijakan yang menekankan pada aspek lokalitas tentunya memerlukan penelitian yang mendalam yang didukung dengan data-data yang valid. Maksud dari desentraliasai pendidikan yakni sesuai dengan UU No.5/1974 yang telah disempurnakan dengan UU No.22/1999 dan UU No.25/1999. Desentralisasi pendidikan sudah disosialisasikan sejak tahun 1980an oleh Mendiknas. Bank Dunia dalam hal ini juga mendukung diberlakukannya kebijakan desentralisasi pendidikan di 40 negara berkembang (Bjork, 2005: 1-2). Seiring dengan itu, sekolah-sekolah yang masih dalam kondisi memprihatinkan harus mendapatkan bantuan yang memadai dari pemerintah karena beban mereka akan semakin berat dengan kebijakan standarisasi UN. 
Potret Kegelisahan Sekolah dalam...; M. Imam Zamroni, M.Si

\section{Pembahasan}

\section{Potret kegelisahan sekolah}

Selain kurikulum di sekolah, terdapat beberapa elemen penting yang dapat menunjang prestasi siswa di sekolah yaitu; guru, siswa, fasilitas pembelajaran dan orang tua siswa. Paling tidak antara guru dan orang tua siswa harus sinergis untuk mendorong anak-anaknya giat belajar, namun dalam masyarakat pedesaan pendidikan anak masih dibebankan oleh sekolah seutuhnya. Partisipasi masyarakat untuk men-supportanak-anaknya di sekolah rendah sekali. Sekolah dianggap sebagai "pabrik" yang dapat memproduksi dan mencetak anak-anak dari bodoh menjadi pintar, dari idiot menjadi cerdas dan dari tidak tahu menjadi tahu segalanya. Dalam kasus UN saya ingin menyoroti tiga halguru di sekolah, siswa dan orang tua siswa - karena tiga komunitas ini yang paling resah dan gelisah terhadap kebijakan standarisasi kelulusan dalam UN, sehingga menyebabkan anak menjadi stress dan depresi dan mendorong mereka untuk mengambil jalan pintas untuk menuai kesuksesan.

\section{Guru di sekolah}

Mengingat peranan strategis guru dalam setiap upaya peningkatan mutu, relevansi dan efisiensi pendidikan, maka guru harus professional dan berkualitas baik. Kemajuan prestasi siswa banyak bergantung pada kepiawaian guru dalam membelajarkan siswa (Supriyadi, 2000: 179) serta lingkungan pembelajaran yang mendukung proses belajar mengajar. Ketergantungan siswa terhadap peran guru dalam peningkatan prestasi dan kemajuan siswa menjadikan tanggungjawab guru semakin besar dan kian berat, meksipun hak yang diterima (insentif), terutama guru swasta, relatif kecil dan tidak jarang tidak bisa mencukupi untuk memenuhi kebutuhan hidup sehari-hari dalam keluarganya mereka harus melakukan kerja sampingan di luar jam sekolah (Zamroni, 2008a). Antara guru swasta dan guru negeri terdapat kesenjangan kesejahteraan sosial yang teramat dalam, meskipun berbagai kebijakan publik untuk mensejahterakan kehidupan guru swasta, namun dlaam praktiknya masih jauh dari harapan.

Dalam konteks pelaksanaan UN di sekolah, keberadaan guru dianggap sebagai sesosok orang yang paling bertanggungjawab jika terdapat siswa yang mengalami kegagalan dalam UN. Akhirnya hampir di seluruh sekolah, baik tingkat SD, SLTP, dan SLTA, guru yang mengampu mata pelajaran yang diujikan dalam UN menambah jam pelajaran guna membahas soal-soal yang telah di-UN-kan pada tahuntahun yang telah lalu, bahkan dalam praktik di lapangan guru juga membuka lembaga bimbingan belajar guna membantu para siswa. Proses pembelajaran dengan menggunakan media soal-soal ujian hanya bersifat prediksi dengan harapan yang sangat tinggi bahwa soal yang dipelajari tersebut akan diujikan kembali dalam UN yang akan diikuti oleh siswa-siswanya dan jika soal-soal yang sudah dipelajari tersebut tidak keluar dalam UN, maka siswapun akan kecewa, sedih, menangis bahkan sampai depresi karena tidak mampu mengerjakan soal dalam UN (Zamroni, 2008b). Pendekanya, pendidikan bagi siswa menjadi proses yang sangat menakutkan dan bukan menjadi proses yang menyenangkan. Di samping itu, guru juga akan sangat gelisah dan khawatir jika mengetahui siswanya mempunyai kemampuan yang minim dalam proses pembalajaran yang dilakukan, sehingga 
UNISIA, Vol. XXXI No. 69 September 2008

mendorong mereka untuk melakukan pengulangan-pengulangan materi pelajaran (Illich, 2001: 134), bahkan melakukan tindakan-tindakan amoral dan anti kejujuran, seperti yang dilakukan oleh ke delapan belas guru SMA Negeri Lubuk Pakam II (Kompas, 14/04/2008).

Fenomena yang dilakukan oleh guruguru di sekolah dalam menghadapi UN terdapat dua usaha yang dilakukan yaitu usaha lahir dan usaha batin (spiritual). Usaha lahir seperti menambah jam pelajaran, membuat les privat, memberikan materi soal ujian terdahulu dan membahasnya, mengadakan try out, mengikuti bimbingan belajar, dan melakukan drill terhadap soal-soal ujian terdahulu. Menjelang pelaksanaan UN telah terjadi diskriminasi mata pelajaran yang cukup ketat, antara mata pelajaran yang diujikan dalam UN dengan mata pelajaran yang tidak diujikan. Adapun usaha spiritual dilakukan oleh guru, siswa dan terkadang juga melibatkan orang tua dengan mengadakan ritual-ritual keagamaan seperti istighotsah, mujahadah, membaca wirid, melakukan ritual di tengah malam seperti sholat tahajud dan lain sebagainya. Memang di beberapa sekolah yang notabene adalah sekolah agama, kegiatan tersebut sudah lama dilakukan, akan tetapi sejak diberlakukannya standarisasi UN, praktik ritual keagamaan tersebut semakin marak dilakukan di berbagai sekolah di Indonesia dan diberbagai tingkatan sekolah, baik pada level SD/MI maupun SLTA/MA/MAN..

Menurut beberapa guru yang saya wawancarai, dalam tiga tahun terakhir berbagai kegiatan tersebut selalu dilakukan oleh sekolah, baik SD, SLTP, dan SLTA, untuk menghadapi UN. Padahal sebelum diberlakukan standarisasi kelulusan dalam UN dengan nilai yang terus dinaikkan dan mata pelajaran bertambah banyak_enam mata pelajaran-tidak semua sekolah mengadakan kegiatan seperti di atas. Memang ada dimensi positif dan negatifnya dari kebijakan pemerintah tentang standarisasi kelulusan dalam UN. Kegiatan belajar mengajar yang sangat pragmatis di sekolah menjadi meningkat untuk menghadapi UN yang dimotori oleh guru, bahkan terkadang sekolah juga memfasilitasi dengan menghadirkan tutor/ fasilitator dari lembaga bimbingan belajar ke sekolah untuk membimbing mengerjakan soal latihan UN yang sudah disediakan atau mengadakan try out.

Adapun dampak negatifnya muncul diskriminasi terhadap mata pelajaran yang ada di sekolah. Menurut penuturan guru di Ngawi, Jawa timur, sekolah mengalokasikan dana yang cukup besar untuk menunjang mata pelajaran yang di-UN-kan sedangkan mata pelajaran yang lain lebih kecil anggarannya. Ironisnya, Komite Sekolah, sebagai pengganti BP3 yang berperan dalam penganggaran (budgeting) di sekolah, juga menyetujui alokasi dana sekolah yang mempunyai efek diskriminatif terhadap mata pelajaran yang ada di sekolah dan berimbas pada "pengucilan" terhadap mata pelajaran yang tidak di-UN-kan. Tidak menutup kemungkinan peristiwa tersebut juga terjadi di berbagai wilayah yang ada di Indonesia. Ini adalah salah satu implikasi dari lemahnya pemberdayaan komite sekolah sehingga tidak mampu berpikir jangka panjang dan efek dari kebijakan yang dilegitimasi. Sehingga perlu adanya pemberdayaan komite sekolah, sehingga komunitas ini mengetahui peran dan fungsinya dalam penganggaran di sekolah.

Diskriminasi mata pelajaran ini juga akan menimbulkan kesenjangan pemahaman siswa terhadap mata pelajaran yang diunggulkan dan yang tidak diunggulkan. Disisi lain akibat pemberian 
Potret Kegelisahan Sekolah dalam...; M. Imam Zamroni, M.Si

insentif yang berbeda juga menimbulkan kecemburuan sosial (social envy) dikalangan para guru yang tidak mendapatkan jatah untuk mengajar mata pelajaran yang di-UNkan, karena mereka mendapatkan insentif yang lebih kecil. Sehingga menimbulkan konflik internal yang bersifat laten dan menyebabkan hubungan sosial (social relations) diantara guru yang sudah lama terbangun menjadi kurang harmonis dan menyebabkan munculnya pergunjingan sosial diantara para guru.

\section{Siswa}

Setiap tahun Departemen Pendidikan Nasional mencatat ada 2,25 juta siswa tingkat SMA/SMK/MA yang mengikuti ujian nasioanal. Adapun peserta ujian nasional tahun ini sekitar 2,26 juta orang. Adanya UN selain terdapat peningkatan intensitas belajar siswa dalam rangka menghadapi UN, siswa juga mengalami stres, gelisah bahkan juga depresi karena dibayang-bayangi UN yang dalam beberapa tahun ini pemerintah selalu menaikkan standar kelulusannya menjadi 5,25 dan tidak boleh terdapat nilai di bawah 4,25 dan masih ditambah mata pelajaran yang di-UN-kan sebanyak tiga mata pelajaran sehingga menjadi enam mata pelajaran. Penambahan mata pelajaran dan peningkatan standar kelulusan tersebut ditujukan untuk peningkatan kualitas pendidikan, akan tetapi tahun ini jumlah kelulusan ditingkatan SMA mengalami penurunan yaitu 92,5 persen. Padahal tingkat kelulusan tahun lalu mencapai 93 persen dengan perincian 95,1 persen tingkat kelulusan untuk ujian nasional mata pelajaran IPA, IPS 90,7 persen dan Bahasa 92,1 persen (http:www.tempointeraktif.com).

Para siswa berpikir jam belajar yang ada di sekolah pun tidak mampu untuk menutupi kekurangan dan keterbatasan tersebut.
Akhirnya para siswa, yang mampu dari sisi finansial, mengikuti berbagai macam Bimbingan Belajar (Bimbel) agar rasa takut, stres dan khawatir akan kegagalan dalam UN dapat terkurangi, meskipun hal ini juga tidak menjanjikan keberhasilan dalam UN. Porsi belajar di rumah juga ditingkatkan demi pencapaian kelulusan itu, yang berarti bahwa partisipasi masyarakat dalam pendidikan anak-anak mereka meningkat. Pendeknya, tidak ada waktu senggang, bersantai maupun bermain bagi para siswa menjelang pelaksanaan UN kali ini, semua gerak-langkah dan pikiran ditujukan untuk memperoleh angka yang tinggi dalam UN yang saat ini masih dianggap sebagai "dewa penyelemat" bagi perjalanan seseorang maupun karir di dunia pendidikan.

Beban psikologis yang berlebihan dirasakan oleh siswa, menjadikan pendidikan semakin memberatkan dan bukan menjadi suatu proses yang menyenangkan, menggembirakan dan membebaskan. Siswa terikat dengan jadwal yang padat untuk memenuhi target kelulusan dalam UN karena terdapat kebijakan pemerintah untuk meningkatkan jumlah materi yang diujikan ketika sudah mendekati UN. Dalam kasus UN, siswa mempunyai beban psikologis yang sangat berat karena mereka harus menanggung malu jika mengalami kegagalan dalam UN. Akibat beban psikologis yang terlalu berat bagi seorang siswa yang masih membutuhkan "ruang " untuk bermain, terkadang mereka juga mengalami gangguan kesehatan fisik dan proses belajar menjadi tidak optimal. Badasarkan penuturan beberapa orang tua siswa yang saya temui, beberapa diantaranya mereka, anak-anaknya jatuh sakit setelah menempuh UN karena kegiatan yang sangat padat. 
UNISIA, Vol. XXXI No. 69 September 2008

Kegelisahan siswa diharapkan dapat diminimalisir dengan melakukan ritual-ritual keagamaan sesuai dengan kepercayaan dan keyakinan masing-masing, seperti istighotsah, sholat dhuha, mujahadah dan lain sebagainya. Pendeknya siswa merupakan kelompok yang paling gelisah dibandingkan dengan kelompok guru maupun kelompok orang tua.

\section{Orang tua siswa}

Orang tua mencurahkan semua perhatiannya untuk mengurangi rasa khawatir terhadap anak-anaknya menjelang pelaksanaan UN dengan mendorong mereka untuk meningkatkan aktifitas belajarnya di rumah maupun di lembaga Bimbingan Belajar (Bimbel). Orang tua yang mampu secara financial terkadang menyuruh anaknya mengikuti Bimbel di beberapa tempat dalam satu waktu. Praksis, di dalam dunia anak-anak tidak ada waktu luang menjelang pelaksanaan UN. Orang tua, siswa dan lembaga Bimbel diwarnai dengan aktifitas pembelajaran yang menekankan pada repetisi soal-soal ujian. Setidaknya ini memberikan sinyal yang baik terhadap perkembangan partisipasi masyarakat dalam pendidikan dan adanya sinergitas antara lembaga pendidikan formal dan non formal.

Akan tetapi terdapat beberapa perubahan terkait dengan keterlibatan orang tua dalam pendidikan anak-anaknya yang semula hanya dilakukan dengan cara-cara rasional seperti meningkatkan kuantitas dan kualitas belajar di rumah. Saat ini orang tua juga melakukan ritual keagamaan dalam menghadapi UN seperti mengerjakan puasa sunnah senin dan kamis, maupun melaksanakan tradisi selamatan. Pendeknya partisipasi orang tua siswa dalam pendidikan anak-anak telah berhasil mengintegrasikan antara aspek rasional dan spiritual, aspek lahiriyah dan batiniyah. Akan tetapi jika dirunut latar belakang partisipasi orang tua tersebut karena sikap pasrah pada nasib atau perasaan fatalistik yang menghantui orang tua ketika mengetahui kemampuan anak-anaknya dan tingginya standar kelulusan yang diberlakukan.

Sikap fatalistik inilah yang mendorong semakin masifnya partisipasi orang tua dalam praktik ritual keagamaan untuk mendukung praksis pendidikan anakanaknya, baik di sekolah maupun di luar sekolah. Disatu sisi memang hal ini dapat memberikan pencerahan spiritual dan peningkatan keimanan seseorang, tetapi di sisi lain hal ini juga dapat melemahkan usaha lahiriah, karena mereka akan beranggapan bahwa semua sudah ditakdirkan dan diatur oleh Yang Maha Kuasa. Praktik pendidikan dan ritual keagamaan seharusnya didasarkan pada kesadaran individual dan panggilan hati nurani seseorang dan bukan didasarkan pada situasi dan kondisi "terpaksa", karena kesadaran merupakan proses dialogis dalam diri seseorang dalam upaya memecahkan masalah yang dihadapi secara bersama-sama (Smith, 2001:4). Inilah yang harus dirubah terkait dengan pengembangan dan kontinuitas partisipasi masyarakat dalam praksis pendidikan.

\section{Dari kesadaran naif ke kesadaran magis}

Dalam menganalisis perubahanperubahan keterlibatan masyarakat di dunia pendidikan serta perubahan paradigma berpikir serta keresahan sosial yang dialami oleh guru dan siswa dalam konteks pelaksanaan UN terdapat tiga paradigma yang dapat digunakan yaitu, paradigma konservatif, yang menekankan pada aspek 
Potret Kegelisahan Sekolah dalam...; M. Imam Zamroni, M.Si

individu/subyek jika terdapat suatu persoalan. Paradigma liberal, yang beranggapan bahwa masalah masyarakat dan pendidikan adalah dua masalah yang berbeda dan paradigma kritis, memandang bahwa proses pendidikan sebagai arena melakukan refleksi kritis terhadap persoalanpersoalan yang muncul. Adapun ketiga paradigma tersebut mempunyai implikasi tiga kesadaran yaitu kesadaran magis yang mengandalkan aspek kekuasaan supra natural/kausa prima (takdir) dalam memandang suatu masalah. Kesadaran naif, memandang aspek manusia yang menjadi penyebab masalah yang muncul dalam masyarakat dan kesadaran kritis, yang melihat system dan struktur sebagai penyebab problematika yang muncul di masyarakat (Fakih dkk, 2001: 18-23, Smith, 2001: 97-101).

Kegelisahan orang tua yang diiringi dengan peningkatan kesadaran mampu meningkatkan partisipasi masyarakat dalam pendidikan yang merupakan wujud penguatan sosial untuk transformasi praksis pendidikan. Di samping itu munculnya aspek religius dalam partisipasi masyrakat mempunyai dampak positif terhadap pengembangan spiritual seseorang, meskipun dalam keadaan "terpaksa". Hampir tidak ada jalan keluar yang diperoleh atau jawaban yang pasti untuk menghadapi UN, baik guru, orang tua siswa dan siswa yang bersangkutan, maka mereka menambatkan segala keinginannya kepada kekuatan supranatural Sang Penguasa Alam ini, meski hanya bersifat temporar. Karena usaha dan jerih payah yang dilakukan telah menguras seluruh tenaga dan pikiran yang terkadang berimbas pada melemahnya aspek psikologis anak dan fisik.

Praktik keagamaan yang terus mencuat-seperti tahlil, mujahadah, dan istighotsah—di berbagai sekolah menjelang
UN dilaksanakan adalah fenomena baru yang tidak banyak ditemukan sebelum diberlakukan standarisasi kelulusan oleh pemerintah yang dalam hal ini adalah Departemen Pendidikan Nasional (Depdiknas). Oleh karenanya harus mendapatkan supportifitas dari berbagai pihak dengan memperhatikan aspek keragaman agama yang ada dalam masyarakat. Sinyal partisipasi ini juga harus dikembangkan ke arah yang lebih luas untuk pengembangan pendidikan, karena partisipasi masyarakat merupakan modal sosial (social capital) yang amat berharga dan dapat memberikan kontribusi yang sangat penting dalam pembangunan pendidikan, ekonomi, sosial, budaya dan politik.

Terkait dengan partisipasi masyarakat dalam pendidikan anak-anaknya, terdapat sinyal perubahan kesadaran, dari rasional ke religius atau meminjam istilah Paulo Freire, dari kesadaran naif ke kesadaran magis. Mereka yang semula hanya mengandalkan ikhtiar secara rasional dan jasadiyah berubah menjadi ikhtiar secara religius karena tidak mampu lagi mengkalkulasi secara rasional persoalanpersoalan yang dihadapinya. Oleh karenanya femonena tersebut harus mendapatkan penguatan rasional agar partisipasi masyarakat menjadi lebih terintegrasi dan mempunyai dampak positif bagi pengembangan keagamaan seseorang dan usaha lahiriyah yang dilakukan. Mereka tidak lagi terjebak pada kubangan kesadaran magis yang hanya mengandalkan kekuatan supranatural, bersikap pasrah dan terkesan "mengkambinghitamkan" takdir jika mengalami kegagalan, sehingga semakin memperkuat virus sikap fatalistik yang mulai tumbuh dan berkembang.

Indikator peningkatan peran serta masyarakat dalam dunia pendidikan yang 
UNISIA, Vol. XXXI No. 69 September 2008

berangkat dari kegelisahan dan kekhawatiran merupakan hal baru dalam pendidikan di Indonesia. Karena dalam menghadapi kompetisi global sekolah saja tidak akan pernah cukup, perlu upaya-upaya komplementer untuk menciptakan kualitas sumber daya manusia yang baik seperti halnya mengintegrasikan antara gerak rasional dan spiritual.

\section{Penutup}

Guru, siswa dan orang tua siswa merupakan elemen penting dalam praksis pendidikan di sekolah. Untuk menunjang keberhasilan siswa dalam meningkatkan prestasinya maka usaha yang dilakukan guru harus bersinergi dengan orang tua. Dalam konteks pelaksanaan UN terlihat dengan jelas tercipta sinergi antara guru dan orang tua siswa namun masih dalam tataran pragmatis yang disebabkan karena kegelisahan dan kekhawatiran orang tua ketika anak-anaknya hendak mengikuti UN. Bahkan lebih dari itu tidak sedikit siswa yang mengalami stres dan depresi karena dibayang-bayangi dengan standar kelulusan yang tinggi, meski para siswa tersebut banyak yang memiliki kemampuan dan kapasitas yang rendah. Maka diperlukan adanya peninjauan kembali kebijakan standarisasi tingkat kelulusan dalam UN karena dalam praktiknya sekolah malah justru terperosok dalam pragmatisme pendidikan yang dan telah terdistorsi. Proses pendidikan tidak lagi berorientasi pada pengembangan potensi siswa sehingga menyebabkan output yang dihasilkan tidak mampu bersaing dalam kompetisi global, sehingga hanya menghasilkan manusia-manusia yang tidak kreatif.

Oleh karenanya selain melakukan kajian yang mendalam sebelum menerapkan kebijakan publik (public policy), maka pemerintah perlu memberikan treatment terhadap sekolah-sekolah yang masih dalam kondisi memprihatinkan, seperti kekurangan guru, fasilitas minim, gedung yang sudah tidak layak pakai, dan lain sebagainya. Jika sekolah sudah ditunjang dengan berbagai fasilitas pembelajaran yang memadai, maka niscaya praktik-praktik kecurangan yang selama ini kita temukan dan wajah stress siswa ketika hendak menghadapi UN akan sirna. Oleh karenanya, dalam hal ini para stakeholder pendidikan hendaknya tidak hanya "menuntut" sekolah untuk memenuhi kebijakan standarisasi yang sudah ditentukan, namun juga memberikan fasilitas yang memadai untuk menunjang pembelajaran.

Anak-anak akan kembali tersenyum dan riang gembira dalam proses belajar di sekolah yang diikutinya. Praksis pembelajaran tidak lagi menjadi proses yang menakutkan dan meneggangkan akan tetapi menjadi suatu hal yang menyenangkan dan menggembirakan bagi anak-anak. Di samping itu kita juga perlu melakukan kajian yang mendalam terhadap kebijakan pemberlakukan standarisasi kelulusan, apakah dapat meningkatkan kualitas pendidikan di Indonesia atau tidak? Sehingga kita dapat mengetahui dampak positif dan dampak negatif yang ditimbulkan serta menginisiasi kebijakan untuk pengembangan pendidikan ke depan dalam menghadapi globalisasi.

\section{Daftar Pustaka}

Bjork, Christopher. 2005. Indonesian Education; Teacher, Schools, and Central Bureaucracy. New York and London, Routledge.

Bourdieu, Pierre dan Passeron, JeanClaude. 1990. Reproduction in Edu- 
Potret Kegelisahan Sekolah dalam...; M. Imam Zamroni, M.Si

cation, Society and Culture. London, Sage Publications.

Fakih, Mansour, dkk. 2001. Pemdidikan Popular; Membangun Kesadaran Kritis. Yogyakarta, Insist.

Freire, Paulo. 2000. Pendidikan Kaum Tertindas. Jakarta, LP3ES.

Harefa, Andrias. 2000. Menjadi Manusia Pembelajar. Jakarta, Kompas.

Jalal, Fasli dan Supriyadi, Dedi (Editor). 2001. Reformasi Pendidikan Dalam Konteks Otonomi Daerah. Yogyakarta, Adicita.

Darmaningtyas. 2007. Realitas Pemberlakukan UAN/UN. EDUKASI Jurnal Penelitian Pendidikan Agama dan Keagamaan. Vol. 5 (1): 41-54.

Illich, Ivan. 2000. Bebaskan Masyarakat dari Belenggu Sekolah. Jakarta, Yayasan Obor.

Nugroho, Benediktus Widi. 2008. Dampak Buruk Ujian Nasional terhadap Siswa, Guru dan Sekolah. Basis. No. 07-08 (57), Juli-Agustus, hal 38-43

Smith, William A. 2001. Conscientizacao; Tujuan Pendidikan Paulo Freire. Yogyakarta, Pustaka Pelajar.

Supriyadi, Dedi. 2000. Mengangkat Citra dan Martabat Guru. Adicita Karya Nusa, Yogyakarta.
Windhu, Marsana. 2000. "Dimensi Kekerasan Tinjauan Teoritis Atas Fenomena Kekerasan". Dalam Suseno, Franz Magnis (ed). Malawan Kekerasan Tanpa Kekerasan.. Yogyakarta, Pustaka Pelajar.

Zakaria, Teuku Ramli. 2005. Ujian Nasional dan Upaya Peningkatan Mutu Pendidikan. Jakarta, Pusat Penilaian Pendidikan, Balitbang Depdiknas.

Zamroni, M. Imam. 2008a. Kesejahteraan Guru Masalah Klasik Pendidikan Kita. Harian Seputar Indonesia, 29 Januari 2008

-2008b. Wajah Stres Pendidikan Kita. Harian Kompas, 22 April 2008 2008c. UN dan Sangkar Besi Pendidikan. Harian Seputar Indonesia, 10 Mei 2008.

Non buku

Kompas, 14 April 2008

Kompas, 03 Mei 2008

Kompas, 12 Agustus 2008

http://www.tempointeraktif.com 